\title{
Multiyear phytoremediation and dynamic of foliar metal(loid)s concentration during application of Miscanthus $\times$ giganteus Greef et Deu to polluted soil from Bakar, Croatia
}

\author{
Valentina Pidlisnyuk $^{1} \cdot$ Pavlo Shapoval $^{2}$ (I) $\cdot$ Željka Zgorelec $^{3} \cdot$ Tatyana Stefanovska $^{4} \cdot$ Oleksandr Zhukov $^{5}$
}

Received: 13 November 2019 / Accepted: 18 May 2020 / Published online: 2 June 2020

(C) The Author(s) 2020

\begin{abstract}
The multiyear cultivation of Miscanthus $\times$ giganteus Greef et Deu (M. $\times$ giganteus) at the soils polluted by metal(loid)s were researched. The biomass parameters and concentrations of elements: $\mathrm{Ti}, \mathrm{Mn}, \mathrm{Fe}, \mathrm{Cu}, \mathrm{Zn}, \mathrm{As}, \mathrm{Sr}$, and Mo were determined in the plant's organs at harvest. The same metal(loid)s were monitored in the plant's leaves throughout three vegetation seasons. The principal component analysis and general linear model approaches were applied for statistical evaluation followed by Box-Cox transformation. The difference in the distribution of elements in the plant, the content of elements in the soil, various regime of uptake to the plant tissues, and the year of vegetation were analyzed as driving factors of the phytoremediation. The results showed that the leading promoter was the factor of the zone, which was the most essential for $\mathrm{Ti}$, $\mathrm{Fe}$, and $\mathrm{Cu}$ and the smallest for $\mathrm{Mn}$. The factor of differences in soil pollution was essential for $\mathrm{Zn}$ and $\mathrm{Mo}$, much less for As, Sr, and Mn, limited for Fe, and was not seen for $\mathrm{Ti}$ and $\mathrm{Cu}$. The factor of the interrelation effects of the zone and experiment reflected the different regime of uptake for the plant tissues was seen for two elements: more prominent for $\mathrm{Cu}$ and smaller for Ti. While analyzing the dynamic of foliar concentrations of the metal(loid)s during 3 years, two groups were defined. Firstly, Fe, Ni, Mn, and $\mathrm{Sr}$ showed stable curves with limited distribution of the plant life cycle. Secondly, $\mathrm{As}, \mathrm{Zn}, \mathrm{Cu}$, and Mo showed different fluctuations in the curves, which can be attributed to essential influence of those elements to the plant life cycle. Further research will be focused on the application of M. × giganteus to the polluted soil in a bigger scale and comparison results of laboratory and field experiments.
\end{abstract}

Keywords Metal(loid)s polluted soil $\cdot$ Rijeka-Bakar area $\cdot$ Miscanthus $\times$ giganteus $\cdot$ Phytoremediation $\cdot$ Dynamic of foliar concentration

Responsible Editor: Elena Maestri

Electronic supplementary material The online version of this article (https://doi.org/10.1007/s11356-020-09344-5) contains supplementary material, which is available to authorized users.

Pavlo Shapoval

pavlo.y.shapoval@1pnu.ua

1 Department of Environmental Chemistry and Technology, Jan Evangelista Purkyně University in Ústí nad Labem, Králova výšina 3132/7, Ústí nad Labem, Czech Republic

2 Department of Physical, Analytical and General Chemistry, National University "Lvivska Polytechnika", Sv.Yura Square 9, Lviv 79013, Ukraine

3 Department of General Agronomy, University of Zagreb, Svetošimunska cesta 25, 10000 Zagreb, Croatia

4 Department of Plant Protection, National University of Life and the Environmental Sciences, Gerojiv Oboronu 13, Kyiv, Ukraine

5 Bogdan Khmelnitsky Melitopol State Pedagogical University, Hetmanska St., 20, Melitopol 72318, Ukraine

\section{Introduction}

Industrial activities represent a valuable source of polluting the environment by toxic elements, which can be introduced into the atmospheric, aquatic, and terrestrial ecosystems (Vareda et al. 2019; Naila et al. 2019; Hui 2020; Rolka et al. 2020). In particular, the negative effect is exacerbated when an industrial zone is located near the water body, and pollutions can move directly to aquifer with additional contamination of the water biota as it was reported for the Venice Lagoon (Gieskes et al. 2015). Another negative case is presented by an industrially polluted zone of the port of Rijeka and Bakar Bay, Croatia where industrial activities between 1970 and 1990 caused regional pollution (Alebic-Juretic 1994; Jakšić et al. 2005). The locations of the main industrial entities in Bakar Bay region are presented in Fig. 1. Since the mid-1990s and after the war, most industries such as the coke factory were cut down, however, the area of Rijeka-Bakar is still 
considered as highly polluted area (Popadić et al. 2013) with tremendous negative impact to the Northern Croatian Adriatic coast including deterioration of water, sediments, soil (Jakšić et al. 2005; Bihari et al. 2007; Alebić-Juretić 2011; Cukrov et al. 2014; Hrelja et al. 2020), bay biodiversity (Ozretić et al. 1990; Perić et al. 2012), and human health (Bartoniček-Brgić and Matković 1989). The urgent request exists to develop the technology for remediation of the area, which has to be effective, not costly, and ecologically friendly.

Varieties of in situ and ex situ approaches are used for remediation of such areas, including surface capping, encapsulation, landfilling, soil flushing or washing, stabilization, solidification and phytoremediation and bioremediation (Liu et al. 2018; Burges et al. 2018). While the main techniques are rather costly and environmentally disturbing, the application of phytoremediation sounds promising, in particular with plants produced a high amount of biomass (Yadav et al. 2018; Antonkiewicz et al. 2019), and was recommended for post-industrial sites (Cunningham and Ow 1996; Chaney et al. 2014). Guarino and Sciarrilli (2017) reported successful application of phytoremediation using two plants with high annual biomass yield: Helianthus annuus L. and Brassica juncea L. when a considerable amount of toxic elements (Cd, $\mathrm{Hg}, \mathrm{Zn}$ ) were taken from soils of the industrial area of Porto Marghera. Phytotechnology with another high biomass yield crop $M$. $\times$ giganteus was proposed for revitalizing of post-mining, technosols, and smelting sites (Wanat et al. 2013; Chaney et al. 2014; Nsanganwimana et al. 2016). Recently, this plant was applied (Kharitonov et al. 2019) for phytoremediation of the industrial zone in Ukraine to soil contended large concentrations of metal(loid)s, industrial disposal in Serbia (Drazic et al. 2017), and post-industrial heavy polluted by metalloids post-mining sites in Poland (Rusinowski et al. 2019). However, there are not many researches on long-term application of M. $\times$ giganteus to post-industrial soil polluted by different metal(loid)s, and only a few publications (Nsangawimana et al. 2015; Pidlisnyuk et al. 2019) reported data on foliar metal(loid)s concentration during vegetation, which may give insight to the process.

The goals of the current study was to test the application of $M$. $\times$ giganteus as phytoremediation agent to the heavy polluted by metal(loid)s post-industrial soil from Bakar, Croatia, to measure the phytoremediation parameters during three vegetation seasons and to observe the peculiarities of metal(loid)s behavior in the plants' organs in the long term. It was intended to define the main promoter factor of the process among differences in element concentration in the soil, years of vegetation, and elements' nature and to compare the behavior of the metal(loid)s in plant's foliar during multiyear growing.

\section{Materials and methods}

\section{The origin of soils}

The polluted soil was taken at Bakar industrial zone, Croatia, from the site with the following coordinates: $45^{\circ} 17^{\prime} 56.7^{\prime \prime} \mathrm{N}$ $14^{\circ} 32^{\prime} 34.4^{\prime \prime} \mathrm{E}$; the soil was sampled on 13 April 2015. The
Fig. 1 The map of point source polluters in Rijeka-Bakar area, Croatia (source: Google Mapsedited by Iva Hrelja, 2017; Hrelja et al. 2020). Polluters: 1 . Shipyard "3. Maj"; 2. Oil refinery INA d.d.-Mlaka plant (closed); 3. Racetracks and airport Grobnik; 4. Industry Zone d.o.o. Bakar; 5. Shipyard "Viktor Lenac"; 6. Oil Refinery INA d.d.-Urinj Plant; 7. Coke Plant Bakar (closed); 8. Bulk Cargo Terminal; 9. DINA d.d.-Organic Petrochemical Company; 10. Rijeka Airport; 11. Power Plant Rijeka. Landfills: 1. Jama Sovjak; 2. Šoići. Protected areas: 1. Nature Park Učka; 2. National Park Risnjak $14^{\circ} 20^{\prime} 0^{\prime \prime} \mathrm{E}$

$14^{\circ} 30^{\prime} 0^{\prime \prime} \mathrm{E}$

$14^{\circ} 40^{\prime} 0^{\prime \prime} \mathrm{E}$

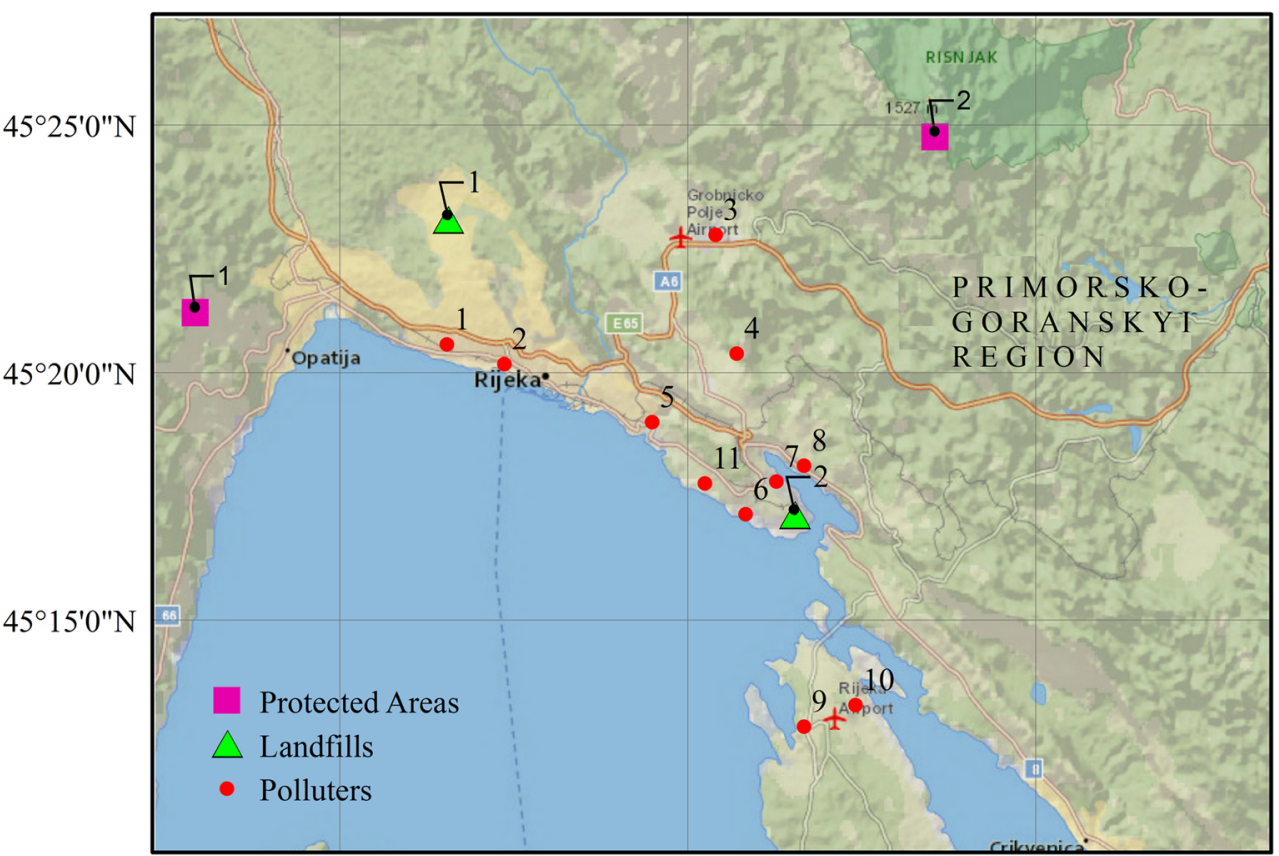


non-polluted soil was taken from the agricultural field located in the village of St. Helena, Zagreb region, with the coordinates: $45^{\circ} 90^{\prime} 50.60^{\prime \prime} \mathrm{N}$ and $16^{\circ} 25^{\prime} 79.89^{\prime \prime} \mathrm{E}$; the non-polluted soil was sampled on 14 April 2015. The soil sampling was done by the ISO standard (ISO 11464, 2001). The process was described in detail at Pidlisnyuk et al. (2018). By classification, the polluted soil was Technosols, and non-polluted soil was Stagnosols (FAO 2015).

\section{Experiment design}

The pots used in the experiment had a volume of 201 ; in each pot, $1 \mathrm{~kg}$ of drainage was put to the bottom, followed by $14 \mathrm{~kg}$ of the research soil. The non-polluted soil was diluted by polluted soil in the following proportions:

\begin{tabular}{llllll}
\hline Scheme of the experiment & 1 & 2 & 3 & 4 & 5 \\
Weight of the non-polluted soil (100\% ) & 100 & 75 & 50 & 25 & - \\
Weight of the polluted soil (100\% ) & - & 25 & 50 & 75 & 100
\end{tabular}

Receiving mixture soils were used for the experiment, which had two replications marked as A and B. The agrochemical parameters of soils were analyzed before the experiment start using the standard's approaches. Data are presented in Table 1.

It may be concluded that non-polluted soil had an excellent quality being rich in the content of primary nutrients: $\mathrm{K}, \mathrm{P}$, and organic matters; however, the content of $\mathrm{N}$ was not entirely sufficient; that soil also had both measured $\mathrm{pH}$ (water and soil extracted) in neutral diapason, while polluted soil was light alkaline. The polluted soil was pure in the content of $\mathrm{P}$ and alkaline hydrolyzed $\mathrm{N}$.

One rhizome of $M$. $\times$ giganteus was planted in each of the pots with an average weight of $20 \mathrm{~g}$. Rhizomes were 3 years old and purchased at the agricultural station "Butsha" (Slovakia). The pots with plants were stored at the open-air throughout vegetation season and watered while necessary by pot water. Upon the end of the vegetation, the above part biomass was harvested and weighted. After that, pots with soil and roots were stored in a dark room throughout winter without watering. The pots were then exposed to light as soon as the first green shoots of M.×giganteus appeared. The experiment continued for three vegetation seasons in 2015-20162017, started on April 15, 2015, when rhizomes were planted to the pots and finished on December 12, 2017. At the end of each vegetation, the samples of plant's organs, leaves, stems, and roots were collected randomly and analyzed for the content of metal(loid)s. The preparation of the plant's organs for the analysis and the analysis breakdown was described in detail earlier (Pidlisnyuk et al. 2018). In parallel, the monitoring of elements' content in the leaves of the plant was done throughout three vegetation seasons (2015-2016-2017). For that, the randomly selected sample of leaves was occasionally taken during vegetation and analyzed.

\section{Analysis of elements in the soil and plant organs}

The content of elements in the soil and plant's organs was analyzed using X-ray fluorescence analysis. The following metal(loid)s were under the investigation: $\mathrm{Ti}, \mathrm{Mn}, \mathrm{Fe}, \mathrm{Cu}$, $\mathrm{Zn}$, As, Sr, and Mo; other elements were neglected being detected in minimal concentrations. Two types of soils were taken for analysis: one sample was taken from the surface of the pot, and another sample was taken from inside of the pot near the roots. The preparation of soil samples and analysis breakdown was described in detail at Pidlisnyuk et al. (2018). Data about elements' content in the research soils are presented in Table 2.
Table 1 The agrochemical parameters of the polluted and non-polluted soils (average \pm standard error)

\begin{tabular}{|c|c|c|c|}
\hline Soil parameter & Polluted soil & Non-polluted soil & Standard \\
\hline $\mathrm{pH}$ (water extracted) & $8.6 \pm 0.60$ & $7.5 \pm 0.51$ & DSTU 8346:2015 \\
\hline pH (salt extracted) & $7.7 \pm 0.54$ & $6.4 \pm 0.40$ & GOST 26483-85 \\
\hline Total salinity (mg/100 g) & $89 \pm 5.56$ & $80 \pm 5.60$ & DSTU 7827:2015 \\
\hline Specific conductivity $(\mu \mathrm{S} / \mathrm{cm})$ & $0.2 \pm 0.01$ & $0.2 \pm 0.01$ & DSTU 8346:2015 \\
\hline Sum of adsorbed alkaline (mmol-equivalent/100 g) & $1.0 \pm 0.05$ & $8.0 \pm 0.52$ & GOST 27821-88 \\
\hline Available S $(\mathrm{mg} / \mathrm{kg})$ & $1.6 \pm 0.10$ & $5.3 \pm 0.31$ & DSTU 8347:2015 \\
\hline Nitrate $\mathrm{N}(\mathrm{mg} / \mathrm{g})$ & $13.2 \pm 0.76$ & $7.6 \pm 0.48$ & DSTU 7629:2014 \\
\hline Alkaline hydrolyzed N (mg/kg) & $5.2 \pm 3.35$ & $137 \pm 7.90$ & DSTU 7863:2015 \\
\hline Available P (mg/kg) & $47 \pm 3.08$ & $238 \pm 16.27$ & DSTU 4115:2002 \\
\hline Available K (mg/kg) & $222 \pm 13.40$ & $404 \pm 27.70$ & DSTU 4115:2002 \\
\hline Available Ca (mmol-equivalent/100 g) & $5.8 \pm 0.32$ & $10.0 \pm 0.51$ & GOST 26487-85 \\
\hline Available $\mathrm{Mg}$ (mmol-equivalent/100 g) & $1.5 \pm 0.08$ & $1.9 \pm 0.10$ & GOST 26487-85 \\
\hline Organic matter $(\%)$ & $6.7 \pm 0.48$ & $8.2 \pm 0.59$ & DSTU 7632:2014 \\
\hline
\end{tabular}




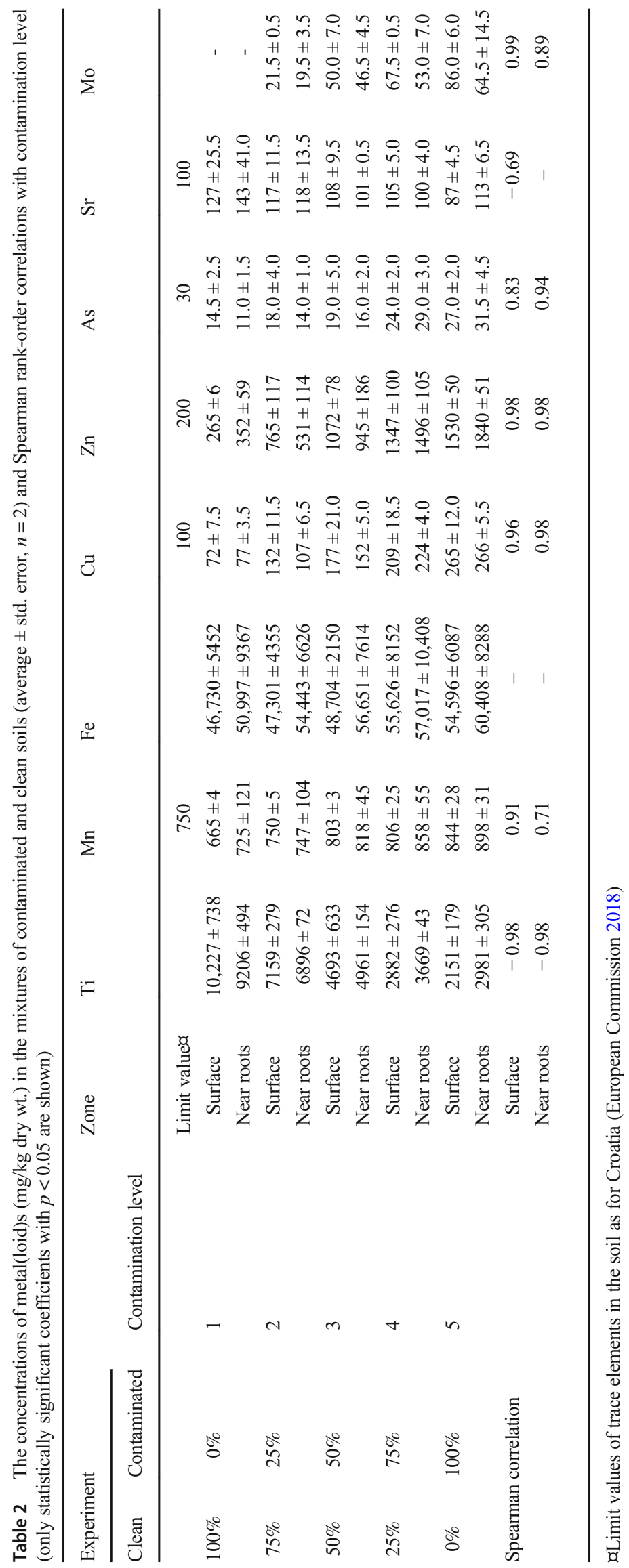


Table 3 Dry $M$. $\times$ giganteus biomass (leaves and stems), $\mathrm{g} /$ per treatment at three harvests

\begin{tabular}{llllllll}
\hline Year & Harvested day & Seria & \multicolumn{5}{l}{ Pollution level } \\
\cline { 3 - 7 } & & & 1 & 2 & 3 & 4 & 5 \\
\hline \multirow{2}{*}{2015} & \multirow{2}{*}{ November 21 } & A & 132.77 & 80.36 & 55.65 & 48.65 & 50.76 \\
& & B & 147.23 & 76.92 & 52.32 & 45.93 & 42.62 \\
2016 & \multirow{2}{*}{ December 22 } & A & 129.95 & 78.65 & 47.81 & 54.85 & 45.58 \\
& & B & 148.45 & 69.92 & 50.60 & 44.77 & 42.87 \\
2017 & \multirow{2}{*}{ December 16 } & A & 125.51 & 74.09 & 40.82 & 57.84 & 41.62 \\
& & B & 145.02 & 67.59 & 46.75 & 41.06 & 39.59 \\
\hline
\end{tabular}

As expected, the element concentrations were increased as a proportion of the polluted soil increase in the mixture. However, those differences varied depending on the elements. The highest increase was observed for $\mathrm{Cu}, \mathrm{Zn}$, and Mo. The last element was not detected in the non-polluted soil. The concentrations of $\mathrm{Fe}$ and $\mathrm{Sr}$ were close. Surprisingly, the concentration of Ti was higher in the non-polluted soil than in the polluted soil, and this might be due to the local background.

\section{Statistics}

The principal component analysis (PCI) and general linear models (GLMs) were applied for statistical evaluation using Box-Cox transformation. The GLMs is an approach used as a numerical solution of ordinary differential equations (Butcher 2016). GLMs were used to assess the effect on the concentration of heavy metals in plant tissues through the categorical predictors (qualitative predictors) - Zone (the effect of the plant zone-roots, leaves, stems), Experiment (the effect of the experiment treatments), and continuum predictors (numerical predictors) - Day (day duration of the vegetation in time of the data collection), as well as their interactions (Zone $\times$ Experiment, Zone $\times$ Day, Experiment $\times$ Day). The calculations were performed in the program Statistica 12.0 (StatSoft Inc., Data Analysis Software System).

The normality is an essential assumption for many statistical techniques, and if data is not normally distributed, applying a Box-Cox makes it possible to run parametric statistical methods. A Box-Cox transformation was applied for the evaluation of research data (Dag et al. 2014). That approach is a way to transform non-normal dependent variables into a normal shape. The Box-Cox transformation has the form:

$y(\lambda)=\left\{\begin{array}{l}\frac{y^{\lambda}-1}{\lambda}, \text { if } \lambda \neq 0 \\ \log y, \text { if } \lambda=0\end{array}\right.$.

where $y$ is the data to be transformed and $\lambda$ is the transformation exponent.

At the core of the Box-Cox transformation is an exponent, lambda $(\lambda)$, which varies from -5 to 5 (Asar et al. 2017). By considering all values, the optimal value that resulted in the best approximation of a normal distribution curve for data was selected. The procedure of the optimal lambda value searching was done utilizing the library AID (Dag and Ilk 2017) for a Language and Environment for Statistical Computing R ( $R$ Core Team 2018). A Spearman rank-order correlation coefficient was applied to reveal the correlation between metal(loid)s concentration and the pollution levels. The GLMs were used to test the significance of the effect of the plant zone (roots, leaves, stems), experimental treatments, and duration of the vegetation on the concentrations of the elements. The PCA was used for dimensionality reduction (Jolliffe 2002). It was applied based on the correlation matrix (as a concentration of elements is on a different scale) and presented in the form of so-called distance biplot.

\section{Results and discussion}

The weight of the harvested dry biomass is presented in Table 3 and showed that the amount was almost the same

Table 4 The concentration of elements ( $\mathrm{mg} / \mathrm{kg}$ dry weight) in the plant organs of $M . \times$ giganteus (average \pm std. error)

\begin{tabular}{|c|c|c|c|c|c|c|c|c|c|c|}
\hline Plant organs & Year & $\mathrm{N}^{*}$ & $\mathrm{Ti}$ & Mn & $\mathrm{Fe}$ & $\mathrm{Cu}$ & $\mathrm{Zn}$ & As & $\mathrm{Sr}$ & Mo \\
\hline \multirow[t]{3}{*}{ Roots } & 2015 & 10 & $714 \pm 102$ & $32 \pm 1.9$ & $5373 \pm 376$ & $34 \pm 5.3$ & $178 \pm 28$ & $1.24 \pm 0.25$ & $28.7 \pm 2.7$ & $5.7 \pm 0.9$ \\
\hline & 2016 & 10 & $799 \pm 103$ & $166 \pm 8.3$ & $6621 \pm 211$ & $48 \pm 11.4$ & $165 \pm 35$ & $3.05 \pm 0.28$ & $17.4 \pm 1.8$ & $4.8 \pm 1.0$ \\
\hline & 2017 & 10 & $689 \pm 116$ & $115 \pm 11.1$ & $6251 \pm 529$ & $63 \pm 10.7$ & $244 \pm 42$ & $4.44 \pm 0.64$ & $43.9 \pm 4.4$ & $13.8 \pm 2.3$ \\
\hline \multirow[t]{3}{*}{ Leaves } & 2015 & 20 & $209 \pm 46$ & $18 \pm 1.4$ & $119 \pm 6.1$ & $4.1 \pm 1.2$ & $45 \pm 5.6$ & $2.41 \pm 0.56$ & $12.5 \pm 0.6$ & $2.3 \pm 0.2$ \\
\hline & 2016 & 60 & $109 \pm 6.3$ & $101 \pm 14.8$ & $216 \pm 13$ & $8.0 \pm 1.3$ & $72 \pm 5.7$ & $1.40 \pm 0.09$ & $14.9 \pm 1.4$ & $4.3 \pm 0.3$ \\
\hline & 2017 & 30 & $47 \pm 2.8$ & $48 \pm 3.4$ & $219 \pm 28$ & $9.5 \pm 1.6$ & $46 \pm 4.0$ & $1.13 \pm 0.12$ & $10.6 \pm 0.9$ & $4.8 \pm 0.5$ \\
\hline \multirow[t]{3}{*}{ Stems } & 2015 & 10 & $33 \pm 2.9$ & $21 \pm 1.8$ & $126 \pm 2.6$ & $2.0 \pm 1.0$ & $203 \pm 35$ & $0.27 \pm 0.03$ & $7.7 \pm 0.7$ & $3.9 \pm 0.5$ \\
\hline & 2016 & 10 & $24 \pm 4.0$ & $38 \pm 7.4$ & $41 \pm 6.9$ & $5.9 \pm 0.7$ & $312 \pm 40$ & $0.76 \pm 0.10$ & $9.6 \pm 1.1$ & $2.4 \pm 0.4$ \\
\hline & 2017 & 10 & $14 \pm 1.2$ & $30 \pm 4.1$ & $42 \pm 4.9$ & $2.4 \pm 1.2$ & $182 \pm 35$ & $0.20 \pm 0.02$ & $2.7 \pm 0.2$ & $0.5 \pm 0.1$ \\
\hline
\end{tabular}

*The number of the replicates 
during three vegetations. As reported (Lewandowski et al. 2000), the development of M.×giganteus improved with vegetation, and plantation intends to be almost established after three vegetation seasons producing a stable amount of biomass with a much higher harvest than in the first 2 years of establishing. That did not happen in the current laboratory experiment, which could be explained by limited surface for root's development in the pots. As expected, the highest value of biomass was received when $M$. $\times$ giganteus grew in the nonpolluted soil (1A and 1B). Moreover, with a dilution of the non-polluted soil even by $25 \%$ of polluted Bakar soil, the value of harvested biomass substantially decreased (2A and 2B). The further soil dilution impacted the decreasing only slightly (3A and $3 \mathrm{~B}$ ) and was almost the same when biomass produced at only polluted soil (5A and $5 \mathrm{~B}$ ).

The concentration of metal(loid)s ( $\mathrm{mg} / \mathrm{kg}$ dry weight) in plant organs upon harvest is presented in Table 4. For that calculation, all replicates measured for one element were joined together.

In Table S1-8 (supplemented materials), the statistically evaluated results on the dependence of each monitored element concentrations in the different plant's organs as
Fig. 2 The concentration of the elements in $M$. × giganteus organs (variable "Zone") depending on the level of soil pollution (time is presented as covariant) using the GLMs model. In this model, the abscissa axis is soil contamination level presented as the attracted level of soil dilution; the ordinate axis is attracted concentrations of elements $(\mathrm{mg} / \mathrm{kg})$ after the BoxCox transformation (average \pm standard deviation)
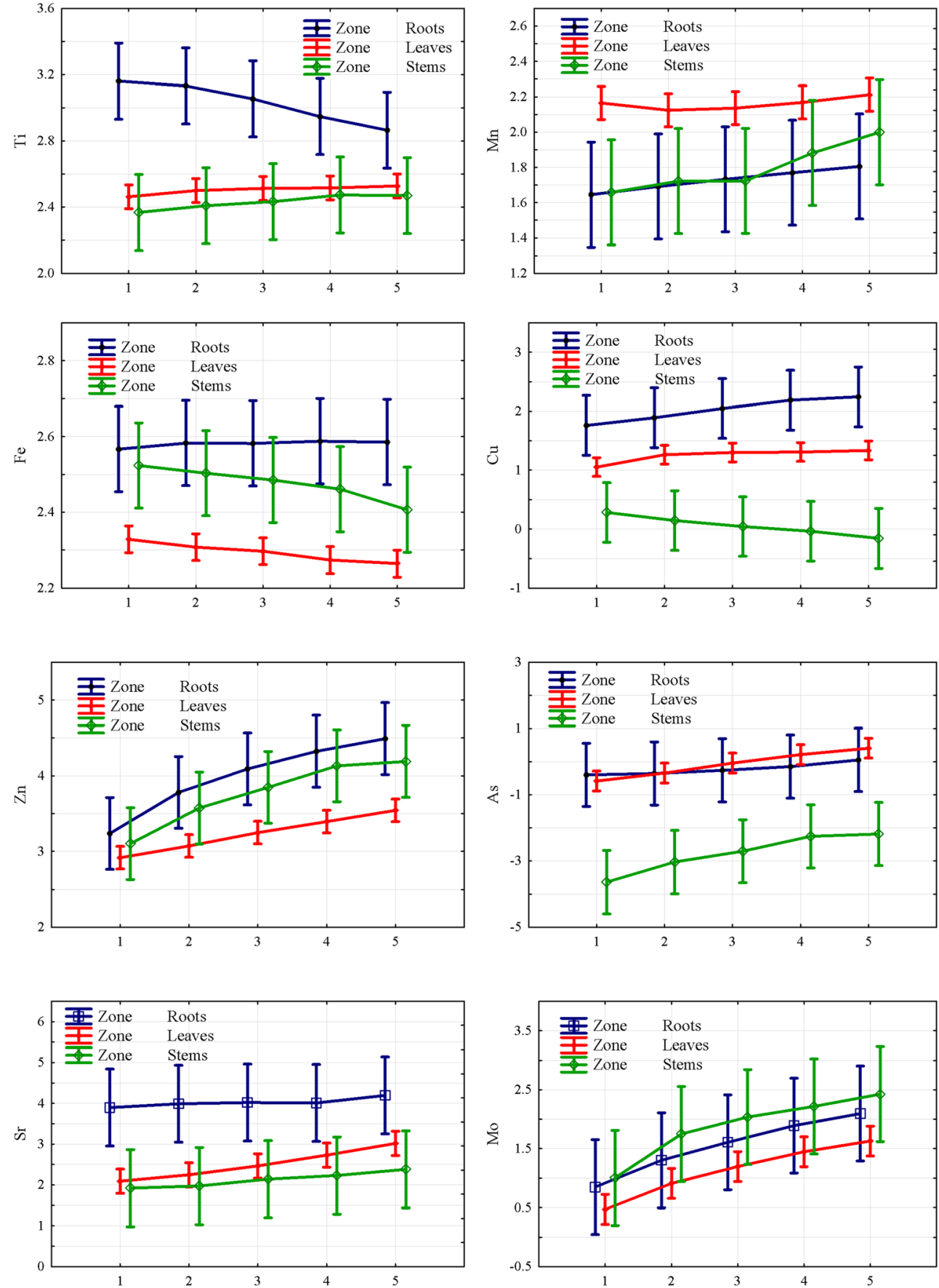
impacted by the level of soil pollution by that element are presented. The impact of the metal(loid)s' nature to the distribution between the plant's parts depending on the level of soil pollution was summed up in Fig. 2.

It can be concluded that the phytoremediation behavior of elements in plant tissues was different and could be grouped as follows: for $\mathrm{Zn}$ and $\mathrm{Fe}$, the situation was the same as for M. $\times$ giganteus phytoremediation when plants grew in slightly metal(loid)s polluted post-military soil (Pidlisnyuk et al. 2019). For the case of heavy polluted post-mining soils (Rusinowski et al. 2019), the highest concentration of elements was distributed to the roots, followed by stems and leaves. This distribution is typical for the phytostabilization process observed with $M$. $\times$ giganteus when the crop is applied to the metal(loid)s contaminated soils (Nsanganwimana et al. 2014). For $\mathrm{Ti}, \mathrm{Cu}$, and $\mathrm{Sr}$, the highest amount also was observed in the roots, however, followed by leaves and then by stems. The behavior of Mn and Mo was different from the highest distribution to above part biomass (leaves in the case of Mn and stems in the case of Mo) and less distribution was to the roots.

When analyzing the response of different parts of the plant to increasing concentration of the elements in the soil, it may be concluded that in the case of $\mathrm{Zn}$, As, and Mo, the increase led to direct increase of concentration in all vegetation parts. For Ti, the roots showed a decrease of the uptake with an increasing concentration, whereas the leaves and stems almost did not react to an increase of concentration. For Mn, the plant almost did not exhibit any reaction in all its parts with the increasing of concentration. For $\mathrm{Fe}$, the roots demonstrated no response for an increasing concentration, whereas a decrease of uptake in the above part of the plant was measured with an increase of concentration in the soil. $\mathrm{For} \mathrm{Cu}$, an increase of the element in the soil yields an increase in the roots, whereas the leaves showed no change, and the stems exhibited a decrease. For Sr, the roots showed no changes, whereas a slight increase was observed for the leaves and the stems.

For an understanding of metal(loid)s' behavior and defining the impact of each factor, the components of the concentration of the element vary depending on the experiment treatment (dilution of the soil) and plant zone (roots, leaves, stems) was analyzed. The results are illustrated in Fig. 3.

It can be seen that the primary source of the metal(loid)s concentration variation was a factor of plant organs (variable "Zone"), i.e., redistribution between parts of the plant, which was the most essential for $\mathrm{Ti}, \mathrm{Fe}$, and $\mathrm{Cu}$ and the smallest for $\mathrm{Mn}$. That factor was stressed as important earlier (Medina et al. 2003; Kabata-Pendias 2010). The factor experiment (different levels of soil contamination - variable "Experiment") was the most essential for $\mathrm{Zn}$ and Mo, however, much less for $\mathrm{As}, \mathrm{Sr}$, and $\mathrm{Mn}$, limited for $\mathrm{Fe}$, and was not observed for $\mathrm{Ti}$ and $\mathrm{Cu}$. The factor of the interaction effects of the Zone and Experiment $(1 * 2)$, which reflected the different regimes of uptake for the plant organs was observed for two elements only: bigger for $\mathrm{Cu}$ and smaller for $\mathrm{Ti}$, and for other elements that factor was neglected.

The PCA was used for the generalized samples for 3 years and permitted to determine the specific principal components for each year, which eigenvalues exceed 1. By this criterion, principal components 1 and 2 were selected to be considered further. The principal component 1 in the annual samples explained $46.8-69.5 \%$ of the total concentration variability of the studied elements. To the greatest extent, this component reflected the variety of all metal(loid)s concentration except for $\mathrm{Zn}$ in 2015, and these elements are characterized by the same sign of correlation coefficient. Thus, principal component 1 can be meaningfully considered the total level of metal(loid)s and distinguishes the sensitivity of different morphological parts of the plant to the degree of soil pollution. This assumption is confirmed by the general linear model: the effect of the "Experiment" factor is statistically significant (Table S9- supplemented materials). It should also be noted that there is no statistically significant interaction between the morphological parts of the plant ("Zone") and the pollution level ("Experiment") in its effect on the principal component 1. That is why the principal component 1 may be concluded to reflect the synchronous changes in the physiological process of metal(loid)s uptake within plant organs induced by the total
Fig. 3 The components of the element concentration variation (after Box-Cox transformation) depended on plant organs (variable 1-“Zone"), experiment treatment (variable 2-

"Experiment"), and its interaction $(1 * 2)$ (with vegetation duration as a covariate). Zone - the effect of the plant organs (roots, leaves, stems); Experiment - the effect of the experiment treatments (levels $1-5) ; 1 * 2$ - the interaction effects of the Zone and Experiment.

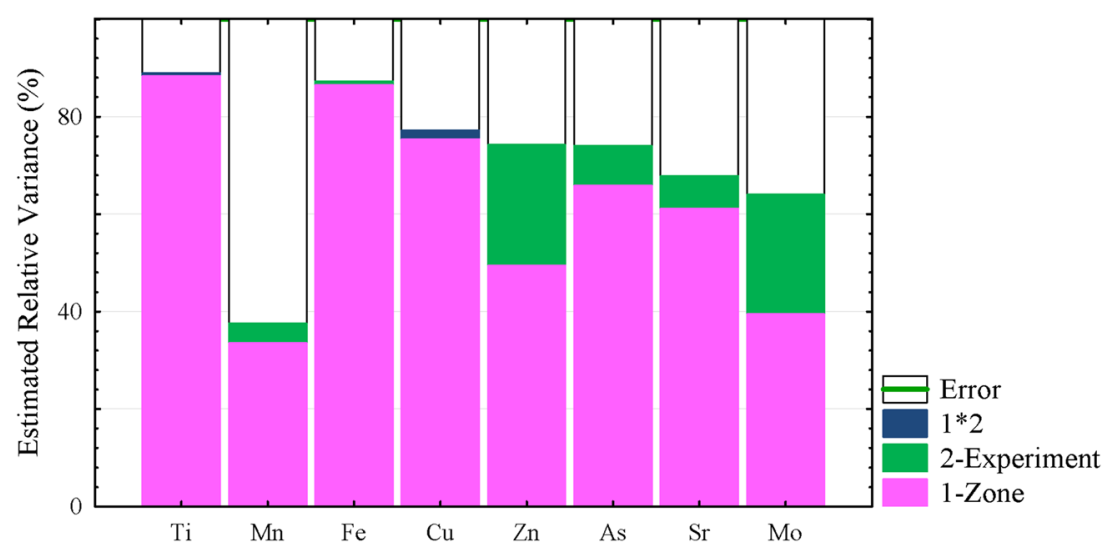


exogenous cause. The soil pollution level is such an exogenous cause. This result may be illustrated by Fig. 4, which shows that increasing of the total level of pollution increases proportionally the content of metal(loid)s in the plant organs while the ratio of its concentration remains unchanged.

Metal(loid)s were accumulated in roots to the greatest extent, followed by leaves and stems. The vegetation duration significantly impacted the accumulation (uptake) of elements by plant organs (significance level 0.067). As a result, this very well expresses that trend is orientated toward decreasing the content of metal(loid)s. It can be assumed that mechanisms counteract the entry of metal(loid)s into the plant developed during its growth.

The principal component 2 explained $14.7 \%$ of the total concentration variability of the studied elements in the generalized sample or 13.0-23.8\% in annual samples. This component is most sensitive to the opposite trend in the dynamics of As and $\mathrm{Zn}$ concentrations. The analyses of the dynamics of the principal component based on the level of pollution indicated that at high levels of soil pollution, the concentration of $\mathrm{Zn}$ in the plants increased while the concentration of As decreased. The regression coefficient of the duration of the vegetation

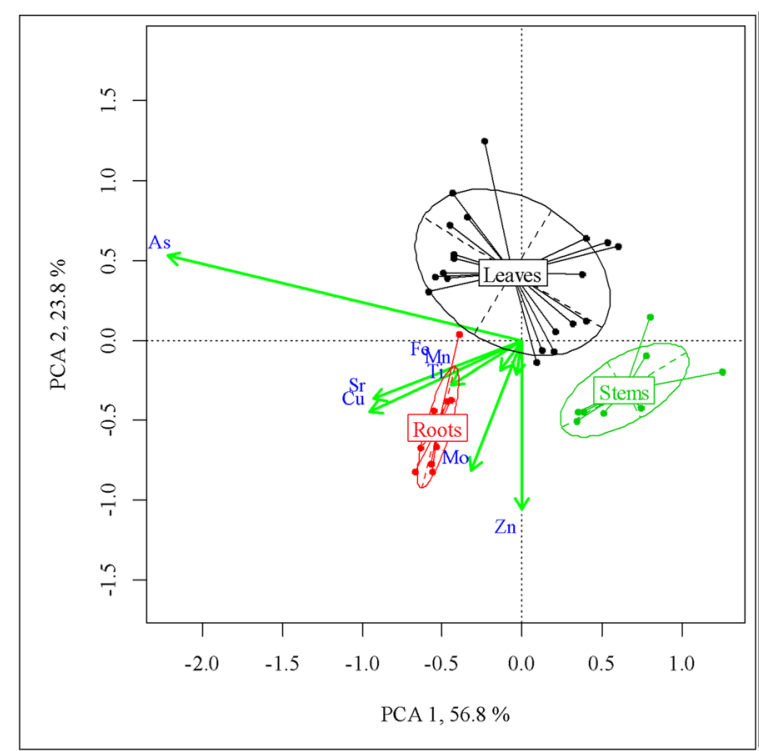

A-2015 year

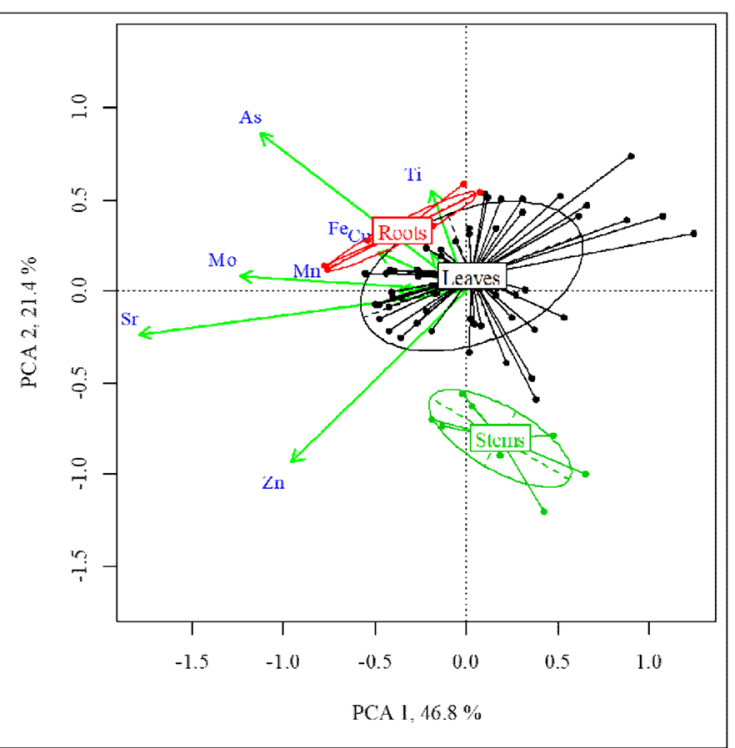

B-2016 year

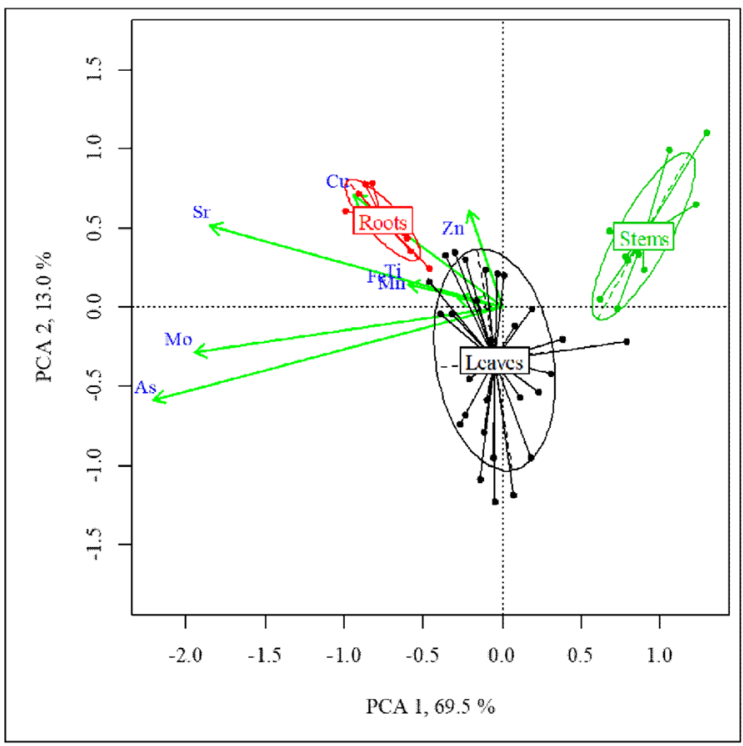

\section{C-2017 year}

Fig. 4 (A)-(C) The application of PCA for to the research system when M. $\times$ giganteus was grown during three vegetation seasons in the metal(loid)s polluted soil 

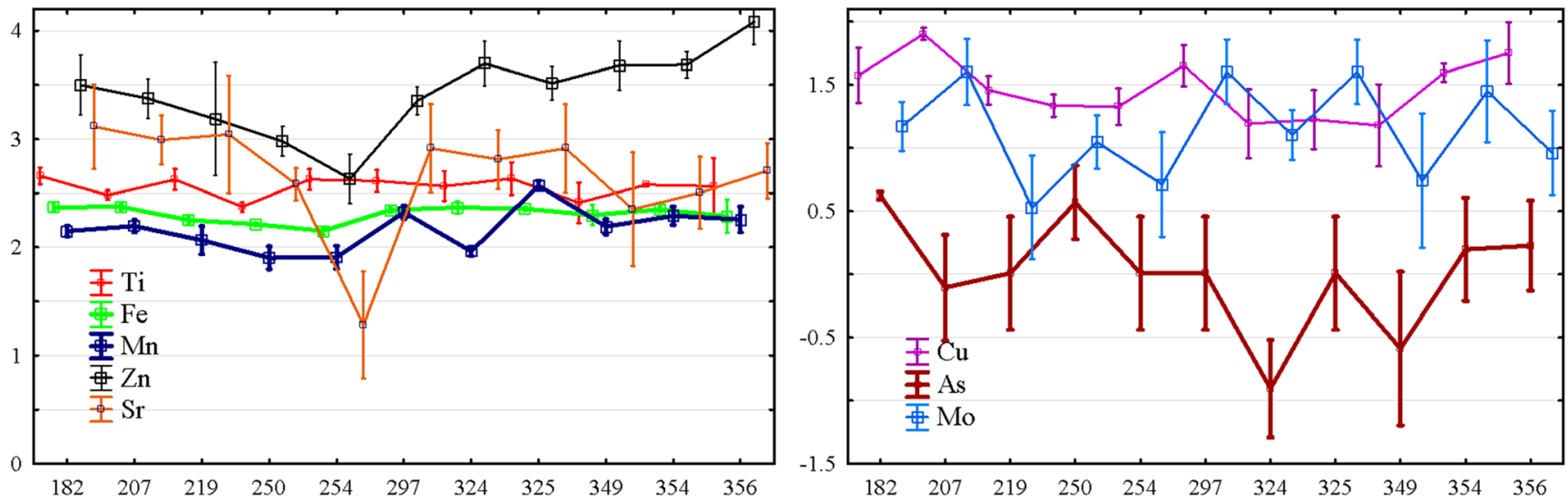

Fig. 5 The dynamic of metal(loid)s concentration in the leaves of $M$. $\times$ giganteus during vegetation period: $x$-axes-the day of vegetation; $y$-axesconcentration of metal(loid)s (in $\mathrm{mg} / \mathrm{g}$ ); time zero indicates planting time

indicated that this trend increased with duration time (Table S10 - supplemented materials). The ratio of $\mathrm{Zn}$ to As concentrations between the plant organs did not change with increasing pollution levels. Thus, principal component 2 can be considered as marker of the endogenous plant response to soil pollution by metal(loid)s. The PCA for each year showed an annual invariance of the relationship discussed earlier between the concentration of metal(loid)s in the plant depending on the level of pollution.

Figure 5 presents the dynamics of the concentration of individual metal(loid)s' variability over time. These dynamics are interrelated, and the nature of this relationship was earlier discussed through the analysis of the principal components. It is also possible to display the weight of each variable for each change (principal component scores) in the temporal dynamics similar to the concentration of an individual metal(loid). However, for this case (Fig. 6), it is referred to the temporal dynamics of principal components 1 and 2 .

The principal component 1 demonstrated the oscillation dynamics in time and described the overall level of metal(loid)s in the plant. It was suggested that the peaks and drops in the metal(loid) contents are associated with the stages of the plant life cycle. For Fe, Ni, and Mn, the curve was almost stable and not determined by the vegetation period, and the only unexpected decrease for $\mathrm{Sr}$ may be referred to as the error with significant probability. So, this group of elements mainly not disturbed the plant life cycle. For other elements, As, $\mathrm{Zn}, \mathrm{Cu}$, and Mo, the fluctuation was evident, so the existence of those elements in the soil impacted the plant's life cycle differently. The principal component 2 indicated the different dynamics of the As and $\mathrm{Zn}$ contents. The analysis of the temporal dynamics of the principal component 2 showed a maximum concentration of As and a minimum concentration of $\mathrm{Zn}$ in the middle period of vegetation of $M$. $\times$ giganteus. It has to be emphasized that the principal component 2 described the minor fraction of metal(loid)s' variability. Therefore, the established trend was not evident in the case of directly considering the temporal dynamics of metal(loid)s. In this way, $t$ As concentration reached the local minimum in the second half of the growing season, while $\mathrm{Zn}$ showed a local minimum
Fig. 6 The dynamic of the principal components $\mathrm{PC} 1$ and PC2 with the time of vegetation: $x$-axes - the day of vegetation; $y$ axes-PC1 and PC2 scores; time zero indicates planting time

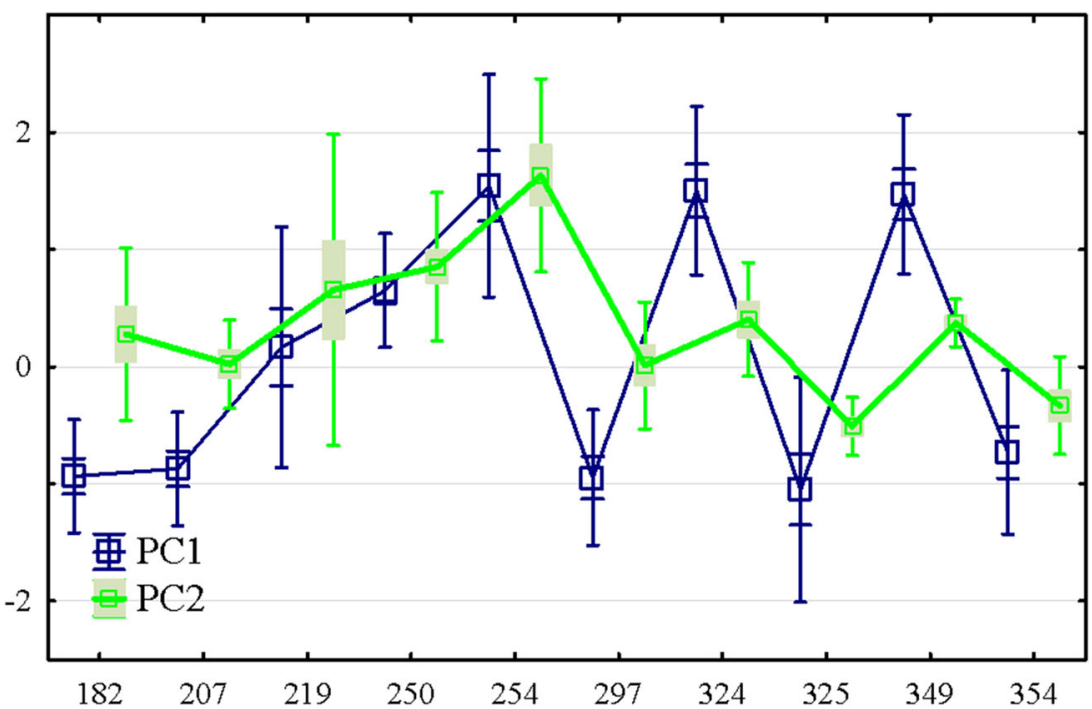


in the first half of the growing season. The uncertainty appeared perhaps because the roles of $\mathrm{Zn}$ and As were prominent in the formation of dynamics, which was described as the principal components 1 and 2 , and were orthogonal (independent) by definition. In other words, at least two independent and essential processes were critical in the dynamics of these two metal(loid)s. Most likely, these are the physiologically normal difference in the distribution of metal(loid)s in the plant organs and the reaction of the plant to soil pollution by metal(loid)s.

The direct analysis of the temporal dynamics of $\mathrm{Mo}$ and $\mathrm{Cu}$ did not allow us to identify a marked trend of variation. The reason can be found in analyzing the principal components of varying the metal(loid)s concentration in the plant for each year separately. For most metal(loid)s, the influence of factors that manifested themselves in the principal components 1 and 2 remained invariant in time, while $\mathrm{Mo}$ and $\mathrm{Cu}$ represented an exception. Thus, $\mathrm{PC} 2$ played a crucial role in varying Mo concentration in 2015, whereas PC1 in 2016 and 2017. For $\mathrm{Cu}, \mathrm{PC} 1$ played a crucial role in 2015 , and consequently, during 2016 and 2017, the role of PC2 was strengthened while the influence of PC 1 remained. The additional research is needed to fully interpret the dynamics behavior of Mo and $\mathrm{Cu}$ because these two elements are sensitive to the varied factors of the different nature presented by the PC1 and $\mathrm{PC} 2$, and this sensitivity is changed considerably over time.

\section{Conclusion}

The phytoremediation process with M.×giganteus in metal(loid)s polluted soil from Bakar, Croatia was studied 3 years in the laboratory conditions. Results showed the proper development of the plant at the highly polluted soil with sufficient biomass production. However, its volume decreased by increasing the level of soil pollution. The concentrations of monitored metal(loid)s: Ti, Mn, Fe, Cu, Zn, As, Sr, and Mo were measured continuously in the plant's tissues at harvest, and through vegetation, the metal(loid) concentrations were monitored in M. × giganteus leaves as well. PCA and GLMs were applied for data evaluation, followed by using Box-Cox transformation. Results showed the differences of metal(loid)s' behavior in the plants' organs depending on vegetation year, the concentration of elements in the soil, and their nature. For $\mathrm{Zn}$ and $\mathrm{Fe}$, the process was typical as for M.×giganteus phytostabilization: the highest concentration of those elements was detected in the roots, followed by stems and leaves. For Ti, $\mathrm{Cu}$, and $\mathrm{Sr}$, the highest uptake was observed to the roots, followed by the leaves and stems. For As, the uptake to the roots and leaves were almost the same while less metal(loid)s moved to the stems. For Mn and Mo, the highest uptake was observed in the upper part of the plant (leaves for Mn and stems for Mo), while fewer uptake was observed to the roots. The main reason for metal(loid) concentrations variation was a factor of the zone: redistribution between parts of the plant was the most essential for $\mathrm{Ti}, \mathrm{Fe}$, and $\mathrm{Cu}$ and the smallest for $\mathrm{Mn}$. The factor experiment (different levels of soil pollution) was valuable for $\mathrm{Zn}$ and Mo, however, much less for As, $\mathrm{Sr}$ and Mn, limited for Fe, and was not observed for $\mathrm{Ti}$ and $\mathrm{Cu}$. The factor of the interrelation effects of Zone and Experiment $(1 * 2)$ reflected the different regimes of uptake to the plant tissues, which was observed for two elements: more prominent for $\mathrm{Cu}$ and smaller for Ti. For other elements, this factor was neglected.

The dynamic of foliar concentrations showed two main groups of the metal(loid)s depending on their influence on the stages of the plant's life cycle. For Fe, Ni, Mn, and $\mathrm{Sr}$, the dynamic curves were almost stable and not determined by the vegetation period, so this group of elements mainly not disturbed the plant's life cycle. The second group of elements was presented by As, Zn, Co, and Mn, which migrations within the leaves varied differently during vegetation, so these elements had an essential influence on the stages of M. $\times$ giganteus life cycle.

Further research will be focused on M.×giganteus application to the post-industrial soil on a bigger scale and comparative correlative analysis between laboratory and field experiments peculiarities.

Funding information The research was supported by NATO SPS MYP G4687. The open access publication was supported by Internal grant agency of J.E.Purkyne University, grant UJEP-IGA-TC-2019-44-01-2.

Open Access This article is licensed under a Creative Commons Attribution 4.0 International License, which permits use, sharing, adaptation, distribution and reproduction in any medium or format, as long as you give appropriate credit to the original author(s) and the source, provide a link to the Creative Commons licence, and indicate if changes were made. The images or other third party material in this article are included in the article's Creative Commons licence, unless indicated otherwise in a credit line to the material. If material is not included in the article's Creative Commons licence and your intended use is not permitted by statutory regulation or exceeds the permitted use, you will need to obtain permission directly from the copyright holder. To view a copy of this licence, visit http://creativecommons.org/licenses/by/4.0/.

\section{References}

Alebic-Juretic A (1994) Precipitation chemistry within Kvarner Bay area, Northern Adriatic (Croatia), 1984-1991. Water Air Soil Pollut 78(3):343-357. https://doi.org/10.1007/BF00483042

Alebić-Juretić A (2011) Air pollution and its impacts-the city of Rijeka case study. In: Moldoveanu AM (ed) Advanced Topics in Environmental Health and Air Pollution Case Studies. IntechOpen. https://doi.org/10.5772/20907

Antonkiewicz J, Kolodziej B, Bielinska EJ, Poplawska A (2019) The possibility of using sewage sludge for energy crop cultivation exemplified by reed canary grass and giant miscanthus. Soil Sci Annu 70(1):21-33. https://doi.org/10.2478/ssa-2019-0003 
Asar O, Ilk O, Dag O (2017) Estimating Box-Cox power transformation parameter via goodness-of-fit tests. Commun Stat Simul Comput 46(1):91-105. https://doi.org/10.1080/03610918.2014.957839

Bartoniček-Brgić V, Matković N (1989) Sulphur dioxide and black smoke air pollution impact on incidence of respiratory diseases among preschool children in Rijeka. Proceedings of the First Yugoslav Clean Air Congress, Book II, pp.734-747, ISBN Zenica, Yugoslavia, June 14-16

Bihari N, Fafandel M, Piškur V (2007) Polycyclic aromatic hydrocarbons and ecotoxicological characterization of seawater, sediment, and mussel Mytilus galloprovincialis from the Gulf of Rijeka, the Adriatic Sea, Croatia. Arch Environ Contam Toxicol 52(3):379387. https://doi.org/10.1007/s00244-005-0259-5

Burges A, Alkorta I, Epelde L, Garbisu C (2018) From phytoremediation of soil contaminants to phytomanagement of ecosystem services in metal contaminated sites. Int J Phytoremediation 20(4):384-397. https://doi.org/10.1080/15226514.2017.1365340

Butcher JC (2016) Numerical methods for ordinary differential equations, 3rd edn. Wiley, p 538. https://doi.org/10.1002/9781119121534 ISBN: 978-1-119-12150-3

Chaney RL, Reeves RD, Baklanov IA, Centofanti T, Broadhurst CL, Baker AJM, Angle JS, van der Ent A, Rosenberg RJ (2014) Phytoremediation and phytomining: using plants to remediate contaminated or mineralized environments. Chapter 15. In: Rajakaruna R, Boyd RS, Harris T (eds) Plant ecology and evolution in harsh environments. Nova Science Publishers, New York, pp 365-391 ISBN: 978-1-63321-955-7

Cukrov N, Frančišković-Bilinski S, Bogner D (2014) Metal contamination recorded in the sediment of the semi-closed Bakar Bay (Croatia). Environ Geochem Health 36(2):195-208. https://doi. org/10.1007/s10653-013-9558-3

Cunningham SD, Ow DW (1996) Promises and prospects of phytoremediation. Plant Physiol 110:715-719. https://doi.org/10. 1104/pp.110.3.715

Dag O, Ilk O (2017) An algorithm for estimating Box-Cox transformation parameter in ANOVA. Commun Stat Simul Comput 46(8):6424 6435. https://doi.org/10.1080/03610918.2016.1204458

Dag O, Asar O, Ilk O (2014) A methodology to Implement Box-Cox transformation when no covariate is available. Commun Stat Simul Comput 43(7):1740-1759. https://doi.org/10.1080/ 03610918.2012 .744042

Drazic G, Milovanovic J, Stefanovic S, Petric I (2017) Potential of Miscanthusxgiganteus for heavy metals removing from industrial deposol. Acta Regionalia et Environmentalica 2:56-58. https://doi. org/10.1515/aree-2017-0009

European Commission 2018 Final implementation report for Directive 86/278/EEC on sewage sludge: 2013-2015. p 156. Available at: http://www.eunomia.co.uk

FAO (2015) World reference base for soil resources 2014. International soil classification system for naming soils and creating legends for soil maps, p 203. E-ISBN 978-92-5-108370-3 (PDF). Available at: http://www.fao.org/3/i3794en/I3794en.pdf

Gieskes J, Han S, Rathburn A, Rothwell G, Perez ME, Porrachi M, Barbanti A, Deheyn DD (2015) Anthropogenic contaminants in Venice Lagoon sediments and their pore fluids: results from the SIOSED project. Mar Chem 174:73-84. https://doi.org/10.1016/j. marchem.2015.05.008

Guarino C, Sciarrilli R (2017) The effectiveness and efficiency of phytoremediation of a multicontaminated industrial site: Porto Marghera (Venice Lagoon, Italy). Chemosphere 183(September): 371-379. https://doi.org/10.1016/j.chemosphere.2017.05.102

Hrelja I, Kisic I, Zgolerec Z (2020) Environmental pollution and ecosystem surveys in Rijeka-Bakar, Croatia-a review. Agric Conspec Sci 85(1):9-17 Available at: https://acs.agr.hr/acs/index.php/acs/article/ view/1645
Hui Z (2020) The experimental research on the behaviors of trace metals. In: Zhang $\mathrm{H}$ (ed) Behaviors of trace metals in environment. The pollution on regional and metropolis areas, vol 2020. Springer, Singapore, pp 253-297. https://doi.org/10.1007/978-981-13-3612-6

Jakšić Ž, Batel R, Bihari N, Mičić M, Karl ZR (2005) Adriatic coast as a microcosm for global genotoxic marine contamination-a long-term field study. Mar Pollut Bull 50(11):1314-1327. https://doi.org/10. 1016/j.marpolbul.2005.04.046

Jolliffe IT (2002) Principal component analysis, Series: Springer Series in Statistics. XXIX, second ed. Springer, NY, p 487. ISBN 978-0-38795442-4. https://doi.org/10.1007/b98835

Kabata-Pendias A (2010) Trace elements in soils and plants. CRC Press, Boca Raton. https://doi.org/10.1201/b10158

Kharitonov M, Pidlisnyuk V, Stefanovska T, Babenko M, Martynva N, Rula I (2019) The estimation of Miscanthusxgiganteus adaptive potential for cultivation on the mining and post-mining lands in Ukraine. Environ Sci Pollut Res 26:2974-2986. https://doi.org/10. 1007/s11356-018-3741-0

Lewandowski I, Clifton-Brown JC, Scurlock JMO, Huisman W (2000) Miscanthus: European experience with a novel energy crop. Biomass Bioenergy 19(4):209-227. https://doi.org/10.1016/S09619534(00)00032-5

Liu L, Li W, Song W, Guo M (2018) Remediation techniques for heavy metal-contaminated soils: principles and applicability. Sci Total Environ 633:206-219. https://doi.org/10.1016/j.scitotenv.2018.03. 161

Medina VF, Maestri E, Marmiroli M, Dietz AC, McCutcheon SC (2003) Plant tolerance to contaminants. In: McCutcheon SC, Schoor JL (eds) Phytoremediation: transformation and control of contaminants. Wiley, p 1890232. ISBN 0-471-39435-1. https://doi.org/10.1002/ 047127304X.ch6

Naila A, Meerdink G, Jayasena V, Sulaiman AZ, Ajit AB (2019) A review on global metal accumulators-mechanism, enhancement, commercial application, and research trend. Environ Sci Pollut Res 26(26):26449-26471. https://doi.org/10.1007/s11356-019-05992-4

Nsanganwimana F, Pourrut B, Mench M, Douay F (2014) Suitability of Miscanthus species for managing inorganic and organic contaminated land and restoring ecosystem services. A review. J Environ Manag 143:123-134. https://doi.org/10.1016/j.jenvman.2014.04. 027

Nsanganwimana F, Waterlot C, Louvel B, Pourrut B, Douay F (2016) Metal, nutrient and biomass accumulation during the growing cycle of Miscanthus established on metal-contaminated soils. J Plant Nutr Soil Sci 179(2):257-269 https://doi.org/10.1002/jpln.201500163

Nsangawimana F, Pourrut B, Waterlot C, Louvel B, Bidar G, Labidi S, Fontaine J, Muchembled J, Lounes-Hadj SA, Fiourrier H, Douay F (2015) Metal accumulation and shoot yield of Miscanthusxgiganteus growing in contaminated agricultural soils: insights into agronomic practices. Agric Ecosyst Environ 213(5): 61-71. https://doi.org/10.1016/j.agee.2015.07.023

Ozretić B, Krajnović-Ozretić M, Santin J (1990) As, Cd, Pb, and Hg in benthic animals from the Kvarner-Rijeka Bay region, Yugoslavia. Mar Pollut Bull 21(12):595-598. https://doi.org/10.1016/0025326X(90)90610-K

Perić L, Fafanđel M, Glad M, Bihari N (2012) Heavy metals concentration and metallothionein content in resident and caged mussels Mytilus galloprovincialis from Rijeka bay, Croatia. Fresenius Environ Bull 21(9):2785-2794 ISSN: 1018-4619. Web of Science Id: WOS:000310112100012

Pidlisnyuk V, Erickson L, Trögl J, Shapoval P, Davis L, Popelka J, Stefanovska T, Hettiarachchi G (2018) Metals uptake behavior in Miscanthus $\mathrm{x}$ giganteus plant during growth at the contaminated soil from the military site in Sliač, Slovakia. Pol J Chem Technol 20(2): 1-7. https://doi.org/10.2478/pjct-2018-0016

Pidlisnyuk V, Erickson L, Stefanovska T, Popelka J, Hettiarachchi G, Davis L, Trogl J (2019) Potential phytomanagement of military 
polluted sites and biomass production using biofuel crop Miscanthus x giganteus. Environ Pollut 249:330-337. https://doi. org/10.1016/j.envpol.2019.03.018

Popadić A, Vidović J, Ćosović V, Medaković D, Dolenec M, Felja I (2013) Impact evaluation of the industrial activities in the bay of Bakar (Adriatic Sea, Croatia): recent benthic foraminifera and heavy metals. Mar Pollut Bull 76(1-2):333-348. https://doi.org/10.1016/j. marpolbul.2013.09.039

R Core Team (2018) A language and environment for statistical computing. R Foundation for Statistical Computing, Vienna https://www. R-project.org

Rolka E, Zolnowski AC, Sadowska MM (2020) Assessment of heavy metal content in soils adjacent to the DK16-route in Olsztyn (NorthEastern Poland). Pol J Environ Stud 29(6):1-9. https://doi.org/10. $15244 /$ pjoes/118384

Rusinowski S, Krzyzak J, Sitko K (2019) Cultivation of C4 perennial energy grasses on heavy metal contaminated arable land: impact on soil, biomass, and photosynthetic traits. Environ Pollut 250:300 311. https://doi.org/10.1016/j.envpol.2019.04.048
Vareda JP, Valente AJM, Duraes L (2019) Assessment of heavy metal pollution from anthropogenic activities and remediation strategies: a review. J Environ Manag 246:101-118. https://doi.org/10.1016/j. jenvman.2019.05.126

Wanat N, Austruy A, Joussein E, Soubrand M, Hitmi A, GauthierMoussard C, Lenain JF, Vernay P, Munch JC, Pichon M (2013) Potentials of Miscanthusxgiganteus grown on highly contaminated Technosols. J Geochem Explor 126-127:78-84. https://doi.org/10. 1016/j.gexplo.2013.01.001

Yadav KK, Gupta N, Kumar A, Reece LM, Singh N, Rezania S, Khan SA (2018) Mechanistic understanding and holistic approach of phytoremediation: a review on application and future prospects. Ecol Eng 120:274-298. https://doi.org/10.1016/j.ecoleng.2018.05. 039

Publisher's note Springer Nature remains neutral with regard to jurisdictional claims in published maps and institutional affiliations. 